\title{
Article \\ Biosorption of Zn(II) from Seawater Solution by the Microalgal Biomass of Tetraselmis marina AC16-MESO
}

\author{
Ronald Huarachi-Olivera ${ }^{1,2, *}$, María Teresa Mata ${ }^{1}$, Jorge Valdés ${ }^{3}$ and Carlos Riquelme ${ }^{1}$ \\ 1 Centro de Bioinnovación Antofagasta (CBIA), Facultad de Ciencias del Mar y de Recursos Biológicos, \\ Universidad de Antofagasta, Antofagasta 1270300, Chile; maria.mata@uantof.cl (M.T.M.); \\ carlos.riquelme@uantof.cl (C.R.) \\ 2 Programa de Doctorado en Ciencias Biológicas, Mención en Biología Celular y Molecular, \\ Facultad de Ciencias de la Salud, Universidad de Antofagasta, Antofagasta 1270300, Chile \\ 3 Laboratorio de Sedimentología y Paleoambientes, Instituto de Ciencias Naturales A. Von Humboldt, \\ Facultad de Ciencias del Mar y de Recursos Biológicos, Universidad de Antofagasta, P.O. Box 170, \\ Antofagasta 1270300, Chile; jorge.valdes.saavedra@uantof.cl \\ * Correspondence: ronald.olivera@uantof.cl
}

Citation: Huarachi-Olivera, R.; Mata, M.T.; Valdés, J.; Riquelme, C. Biosorption of $\mathrm{Zn}$ (II) from Seawater Solution by the Microalgal Biomass of Tetraselmis marina AC16-MESO. Int. J. Mol. Sci. 2021, 22, 12799. https:// doi.org/10.3390/ijms222312799

Academic Editor: Vitor Manue Oliveira Vasconcelos

Received: 20 October 2021

Accepted: 14 November 2021

Published: 26 November 2021

Publisher's Note: MDPI stays neutral with regard to jurisdictional claims in published maps and institutional affiliations.

Copyright: (c) 2021 by the authors. Licensee MDPI, Basel, Switzerland. This article is an open access article distributed under the terms and conditions of the Creative Commons Attribution (CC BY) license (https:// creativecommons.org/licenses/by/ $4.0 /)$

\begin{abstract}
Biosorption refers to a physicochemical process where substances are removed from the solution by a biological material (live or dead) via adsorption processes governed by mechanisms such as surface complexation, ion exchange, and precipitation. This study aimed to evaluate the adsorption of $\mathrm{Zn}^{2+}$ in seawater using the microalgal biomass of Tetraselmis marina AC16-MESO "in vivo" and "not alive" at different concentrations of $\mathrm{Zn}^{2+}\left(0,5,10\right.$, and $\left.20 \mathrm{mg} \mathrm{L}^{-1}\right)$ at $72 \mathrm{~h}$. Analysis was carried out by using the Langmuir isotherms and by evaluating the autofluorescence from microalgae. The maximum adsorption of $\mathrm{Zn}^{2+}$ by the Langmuir model using the $\mathrm{Q}_{\max }$ parameter in the living microalgal biomass $\left(Q_{\max }=0.03051 \mathrm{mg} \mathrm{g}^{-1}\right)$ was more significant than the non-living microalgal biomass of T. marine AC16-MESO $\left(\mathrm{Q}_{\max }=0.02297 \mathrm{mg} \mathrm{g}^{-1}\right)$. Furthermore, a decrease in fluorescence was detected in cells from T. marina AC16-MESO, in the following order: $\mathrm{Zn}^{2+}$ $(0<20<5<10) \mathrm{mg} \mathrm{L}^{-1}$. $\mathrm{Zn}^{2+}$ was adsorbed quickly by living cells from $T$. marine AC16-MESO compared to the non-living microalgal biomass, with a decrease in photosystem II activities from 0 to $20 \mathrm{mg} \mathrm{L}^{-1} \mathrm{Zn}^{2+}$ in living cells.
\end{abstract}

Keywords: autofluorescence; adsorption; microalgal; Langmuir

\section{Introduction}

Microalgae have a broad spectrum of mechanisms (extracellular and intracellular) to cope with heavy metal toxicity [1]. Microalgae strains revealed varied tolerance and response along with bioaccumulation capability toward heavy metals. Different functional groups, as well as proteins and peptides, are responsible for the metal-binding characteristics. Mechanisms such as extracellular adsorption, reduction, volatilization, complex formation, ion exchange, intracellular accumulation, chelation, and bio-methylation are involved in the bioremediation and biosorption of heavy metals [2]. "Heavy metals" is a term generally given to metals and metalloids with a density of more than $5 \mathrm{~g} / \mathrm{cm}^{3}$, which include arsenic (As), cadmium $(\mathrm{Cd})$, chromium $(\mathrm{Cr})$, copper $(\mathrm{Cu})$, iron $(\mathrm{Fe})$, lead $(\mathrm{Pb})$, mercury $(\mathrm{Hg})$, silver $(\mathrm{Ag})$, zinc $(\mathrm{Zn})$, and others [3]. Microalgae consume trace amounts of heavy metals such as boron (B), cobalt $(\mathrm{Co})$, copper $(\mathrm{Cu})$, iron (Fe), molybdenum (Mo), manganese $(\mathrm{Mn})$, and zinc $(\mathrm{Zn})$ for the enzymatic processes and cell metabolism. However, other heavy metals such as $\mathrm{As}, \mathrm{Cd}, \mathrm{Cr}, \mathrm{Pb}$, and $\mathrm{Hg}$ are highly toxic to microalgae. Due to the hormesis phenomenon, low concentrations of toxic heavy metals can stimulate the growth and metabolism of microalgae [4]. Zinc is a masculine element that balances copper in the body and is also essential for male reproductive activity [5]. Chemically, $\mathrm{Zn}^{2+}$ is a Lewis acid that can bind to both the phosphate backbone and the nucleobases of the DNA. $\mathrm{Zn}^{2+}$ undergoes hydrolysis even at neutral $\mathrm{pH}$. Furthermore, the partially hydrolyzed 
polynuclear complexes can affect the interactions with DNA. These features make $\mathrm{Zn}^{2+}$ a unique cofactor for DNAzyme reactions [6]. The largest distribution of $\mathrm{Zn}$ is in the water of the intertidal zone of the coastal sector of Bahía San Jorge, near the city of Antofagasta, which represents the highest population density in northern Chile. The coastal area of this bay is used extensively as a dumping ground for different sources of pollutants. $\mathrm{Zn}$ content varies between $1.7 \mu \mathrm{g} \mathrm{L}^{-1}$ in the northern part of the study area to $2.0 \mu \mathrm{g} \mathrm{L}^{-1}$ in front of the industrial discharge zone. The spatial distribution results from the different local contributions and coastal currents that dilute the contributions and movement of the water toward the North [7].

Experimental tests on the chemical forms of zinc in seawater revealed the following results: (1) ionic plus labile form, (2) inorganic complexes and colloids as well as weak organic complexes, and (3) impeded fraction in large organic molecules and/or organic colloids [8].

Adsorption of heavy metals on the surface of microalgae is a rapid process. It can happen via different paths, including forming a covalent bond between ionized cell walls with heavy metals, ionic exchange of heavy metal ions with cell wall cation, and binding of heavy metal cations with negatively charged uronic acids microalgae exopolysaccharides. However, the process of heavy metal accumulation inside the cell is much slower. The heavy metals are transported actively across the cell membrane and into the cytoplasm, followed by diffusion and subsequent binding with internal binding sites of proteins and peptides such as glutathione, metal transporter, oxidative stress-reducing agents, and phytochelatins $[9,10]$. Algae biomass adsorbents used for the adsorptive removal of heavy metal pollutants from wastewater show a promising alternative for a single analyte concerning different empirical isotherm models (i.e., Freundlich, Langmuir, Temkin, Sips, and Redlich-Peterson). Freundlich and Langmuir's models are the most commonly used isotherm models in many studies [11]. For example, blue algae (Cyanophyta) biomass was an excellent sorbent to treat industrial effluents containing $\mathrm{Zn}^{2+}$ ions in single metal systems [12].

Photosynthesis is the most basic physiological process of microalgae. Most of the light energy absorbed by chlorophyll is utilized for photosynthesis. The remaining energy is released in the form of heat and fluorescence. Due to the mutual competition between these three methods for energy, photosynthesis can impact fluorescence emissions. Thus, the chlorophyll fluorescence analysis technology developed in recent years has become a new method for measuring and diagnosing plant living bodies based on the theory of photosynthesis [13].

Furthermore, when contaminants interact with algal cells, the toxic effects of pollutants on algae can be expressed through photosynthesis in the form of a change in chlorophyll fluorescence. Therefore, chlorophyll fluorescence as a probe for biological toxicity analysis has become a new method for comprehensively assessing water pollution [14]. At present, the maximum photochemical quantum yield of PSII $\left(\mathrm{F}_{\mathrm{V}} / \mathrm{F}_{\mathrm{M}}\right)$ as a photosynthesis activity fluorescence parameter is widely used in the toxicity analysis of pollutants [15,16]. However, the other chlorophyll fluorescent parameters were not very efficient in evaluating the toxic effects of toxicants on algae [14].

Fluorescence recovery after photobleaching (FRAP) has been used to study protein diffusion since the 1970s $[17,18]$. FRAP technique is widely used in cell biology to observe the dynamics of biological systems, including the diffusion of membrane components providing information on it. The photosynthetic membrane has been considered an ideal model to study protein mobility, given its naturally fluorescent properties [19]. However, the complexity of the photosynthetic membrane should be considered in FRAP, as the numbers of fluorescent proteins are located densely in the membrane with a close functional association promoting efficient energy transfer [20]. Thylakoid membranes are dynamic systems in which the lateral mobility of proteins and lipids plays a crucial role in physiological processes, including electron transport, regulation of light-harvesting, membrane biogenesis, and turnover and repair of proteins. An optimum density of packing of protein 
complexes into the membrane allows some fluidity in the membrane combined with a high density of photosynthetic complexes and efficient interaction of reaction centers and light-harvesting complexes [21].

The microalga Tetraselmis marina AC16-MESO tolerates and removes high concentrations of metal ions. In addition, it is capable of eliminating these metals at a high rate, within a relatively short time, and with a high sedimentation efficiency. These characteristics make T. marina AC16-MESO a promising candidate for use in bioremediation [22]. This study aimed to evaluate the adsorption of $\mathrm{Zn}^{2+}$ in seawater using the microalgal biomass of Tetraselmis marina AC16-MESO "in vivo" and "not alive" at different concentrations of $\mathrm{Zn}^{2+}\left(0,5,10\right.$, and $\left.20 \mathrm{mg} \mathrm{L}^{-1}\right)$ at $72 \mathrm{~h}$. In the present research, T. marina AC16 MESO "living" and "non-living" microalgal biomass was used as $\mathrm{Zn}^{2+}$ bio adsorbent material and subjected to the Langmuir adsorption isotherm model in the seawater solution at different concentrations of $\mathrm{Zn}^{2+}$.

\section{Results}

2.1. Algal Growth and Maximum Quantum Yield $\left(F_{V} / F_{M}\right)$ from Microalgae Tetraselmis marina AC16-MESO in Bacteriological Agar Medium under Different Concentrations of $\mathrm{Zn}^{2+}$

In Figure $1 C$, the culture of the microalgae Tetraselmis marina AC16-MESO in concentrations from 0 to $10 \mathrm{mg} / \mathrm{L}$ of $\mathrm{Zn}^{2+}$ revealed a constant growth of T. marina AC16-MESO, except R3 of concentration 2 and $10 \mathrm{mg} / \mathrm{L} \mathrm{Zn}^{2+}$. The lowest growth was observed at $20 \mathrm{mg} / \mathrm{L} \mathrm{Zn}^{2+}$ in the repetitions ( $\mathrm{R} 2$ and $\mathrm{R} 3$ ).

In Figure 1D, it is observed that the changes in Chl-a fluorescence measured by the optimal quantum yield of photosystem II (PSII, Fv $/ \mathrm{F}_{\mathrm{M}}$ ), at concentrations of $0.5,2,5,10$, and $20 \mathrm{mg} \mathrm{L}^{-1} \mathrm{Zn}^{2+}$ where the statistical significance between groups was ${ }^{* *} p<0.001$, ** $p<0.01,{ }^{*} p<0.05$ with respect to $0 \mathrm{mg} / \mathrm{L} \mathrm{Zn}^{2+}$.(Tukey's multiple comparison test).
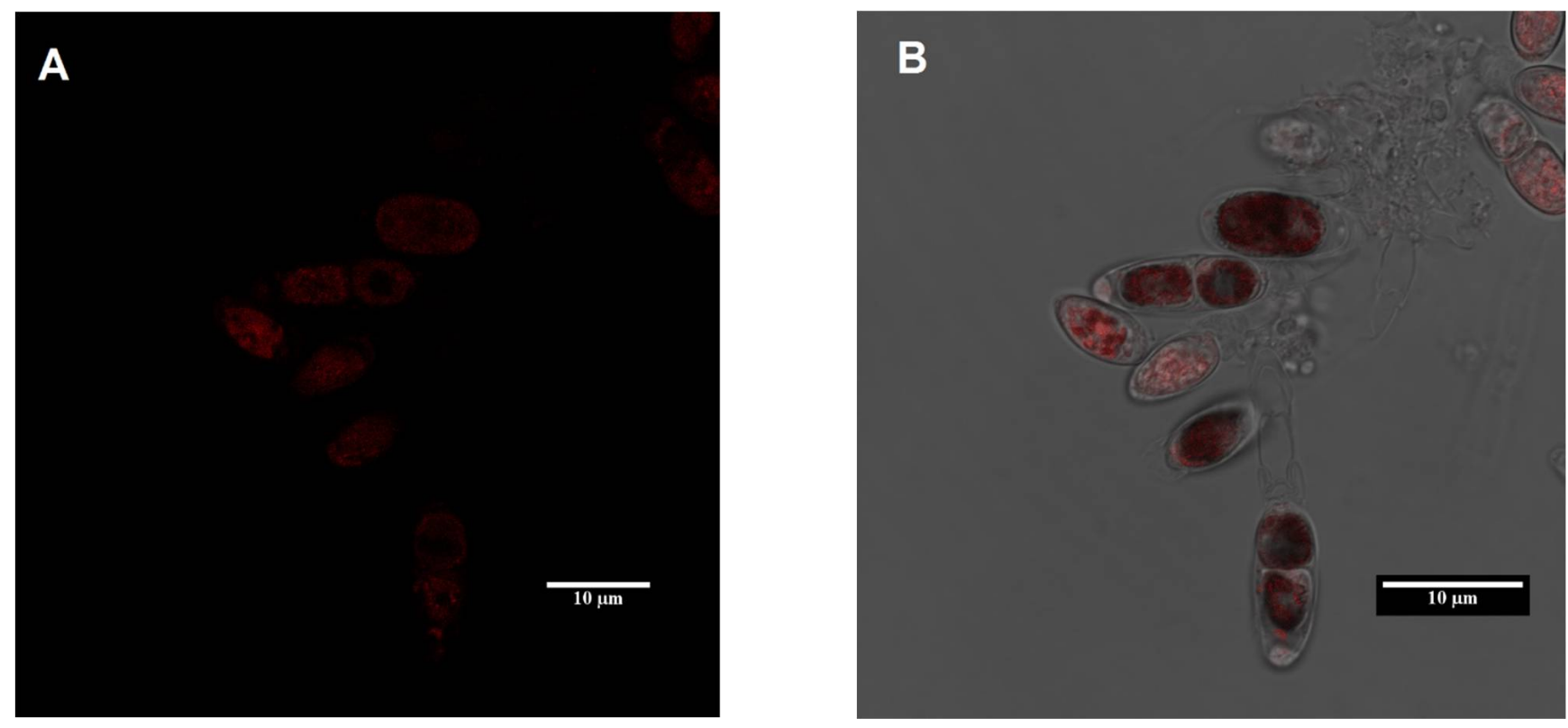

Figure 1. Cont. 

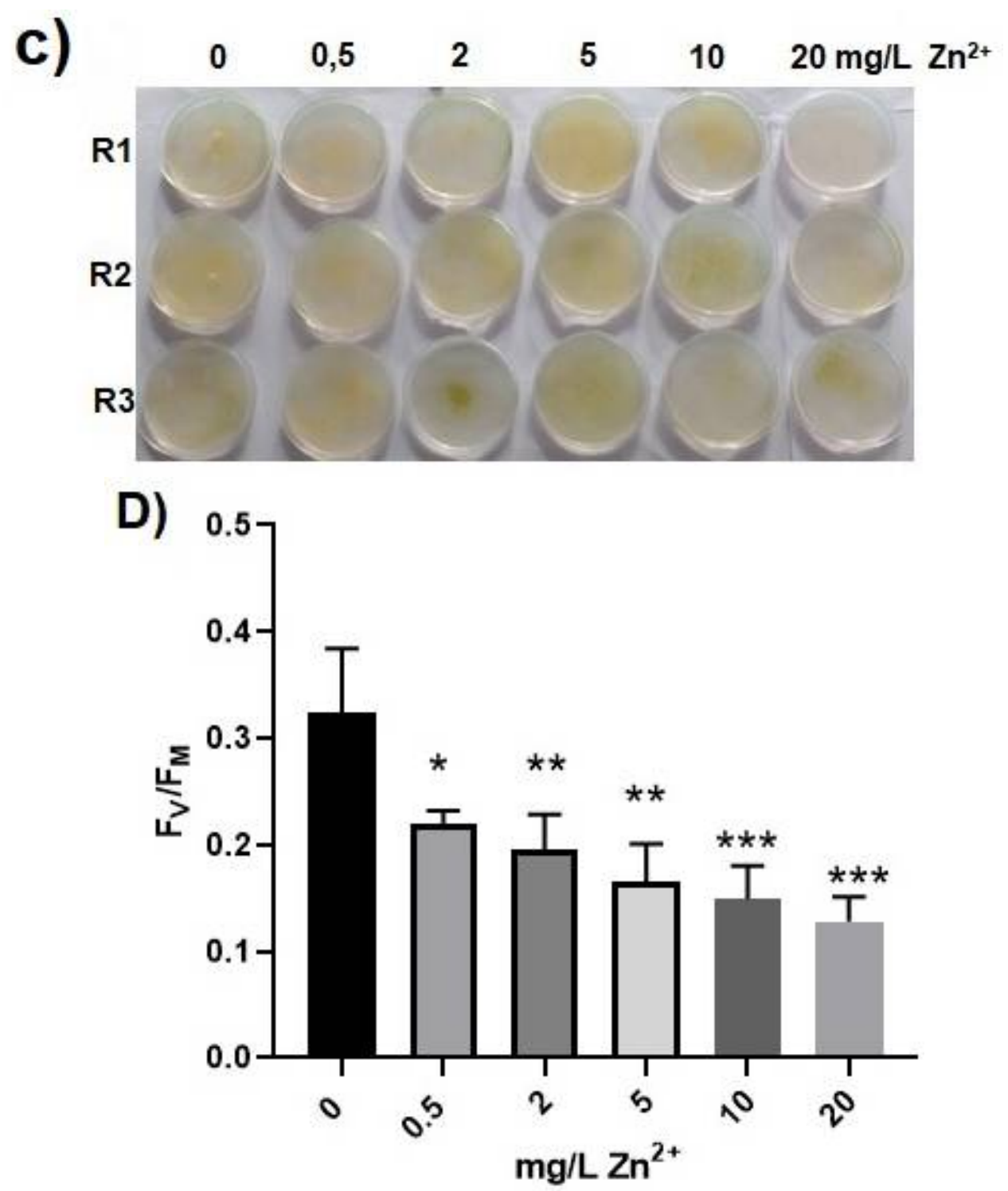

Figure 1. Observation of the microalgae Tetraselmis marina AC16-MESO. (A,B) Photographs of microalgal cells through confocal microscopy. (C) Petri dishes with bacteriological agar medium at different concentrations of $\mathrm{Zn}^{2+}$ after 68 days. (D) Maximum quantum yield $\left(\mathrm{F}_{\mathrm{V}} / \mathrm{F}_{\mathrm{M}}\right)$ in cultures of T. marina AC16 MESO exposed to different $\mathrm{Zn}^{2+}$ treatments for 68 days. Bars indicate the standard error (SE), ${ }^{* * *} p<0.001,{ }^{* *} p<0.01,{ }^{*} p<0.05$ with respect to $0 \mathrm{mg} / \mathrm{L}$ Zn2+ (Tukey's multiple comparison test).

\section{2. $\mathrm{Zn}^{2+}$ Adsorption Experiments in Living and Non-Living Biomass from Tetraselmis marina AC16-MESO}

The fittings of experimental equilibrium to the Langmuir model are represented in Figure 2, and the corresponding fitted parameters are depicted in Table 1. The adsorption capacity of $\mathrm{Zn}^{2+}$ of the live microalgal biomass was more significant than the microalgal dead biomass of T. marina AC16-MESO, which can be confirmed by the values of $\mathrm{Q}_{\max }$ in Table 1. According to the Langmuir isotherm (1918) model, the $Q_{\max }$, which is the maximum adsorption capacity, corresponds to the saturation of a monolayer of adsorbate molecules on the adsorbent surface. When molecules of adsorbate occupy all adsorption sites, each adsorbent has a unique $Q_{\max }$ for each adsorbate. Therefore, $Q_{\max }$ is used to predict adsorbent performance in real systems and for the design of adsorbents at different scales [23]. In this work, the $\mathrm{Q}_{\max }$ determined by the microalgal live biomass 
(0.03051 $\mathrm{mg} \mathrm{g}^{-1}$ ) was significantly higher than the microalgal dead biomass of T. marina AC16 MESO (0.02297 $\mathrm{mg} \mathrm{g}^{-1}$ ) (Table 1).
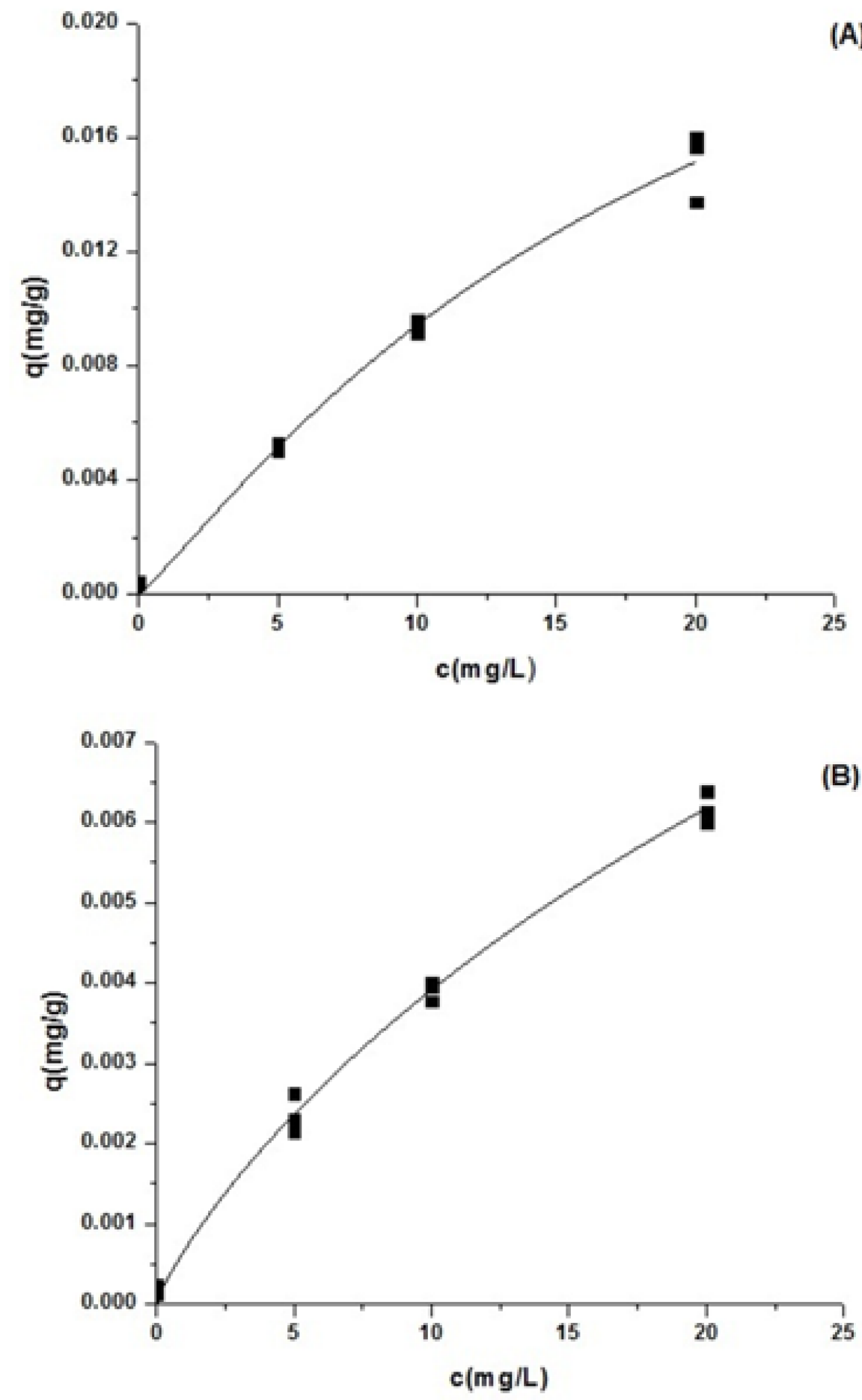

Figure 2. Equilibrium results of the adsorption of $\mathrm{Zn}^{2+}$. (A) Tetraselmis marina AC16-MESO living biomass; (B) Tetraselmis marina AC16-MESO non-living biomass. Experimental data on the equilibrium adsorbed concentration of $\mathrm{Zn}^{2+}\left(\mathrm{q}, \mathrm{mg} \cdot \mathrm{g}^{-1}\right)$ versus the equilibrium $\mathrm{Zn}^{2+}$ concentration in the liquid phase $\left(\mathrm{C}, \mathrm{mg} \cdot \mathrm{L}^{-1}\right)$ represented together and fit into the Langmuir equilibrium isotherm models. 
Table 1. Parameters from fitting the experimental results with equilibrium isotherm (Langmuir equilibrium isotherms) model.

\begin{tabular}{cccc}
\hline \multicolumn{4}{c}{ Equilibrium Isotherms } \\
\hline Model & Parameter & Biomass Microalgae Tetraselmis marina AC-16 MESO \\
\hline & & Non-Living $(\mathrm{mg} / \mathrm{g})$ & Living $(\mathrm{mg} / \mathrm{g})$ \\
\hline Langmuir & $\mathrm{Q}_{\max }$ & 0.02297 & 0.03051 \\
\hline & $\mathrm{K}$ & 0.02964 & 0.03249 \\
\hline $\mathrm{n}$ & 0.84065 & 1.13885 \\
\hline & $\mathrm{r}^{2}$ & 0.99345 & 0.98789 \\
\hline
\end{tabular}

2.3. Microalgal Growth, Evaluation on the Formation of Chlorophylls " $a$ " and " $b$ ", and Maximum Quantum Yield $\left(\mathrm{Fv} / \mathrm{F}_{\mathrm{M}}\right)$ under Different Concentrations of $\mathrm{Zn}^{2+}$

The effect of $\mathrm{Zn}^{2+}$ on Tetraselmis marina AC16-MESO is shown in Figure 3A. A higher concentration of $\mathrm{Zn}^{2+}$ decreases the microalgal growth determined by counting every $24 \mathrm{~h}$ for 3 days.

In Figure 3B,C, the maximum values were found in the negative control $\left(0 \mathrm{mg} \mathrm{L}^{-1}\right.$ $\mathrm{Zn}^{2+}$ ). An increase or decrease is observed in both chlorophylls " $\mathrm{a}$ " and " $\mathrm{b}$ " at different concentrations of $\mathrm{Zn}^{2+}$ without significant differences $(p>0.05)$ (Tukey's multiple comparison test), revealing an intermediate accumulation in concentration of $10 \mathrm{mg} \mathrm{L}^{-1} \mathrm{Zn}^{2+}$. The lowest concentrations of chlorophylls " $a$ " and " $b$ " are observed in 5 and $20 \mathrm{mg} \mathrm{L}^{-1} \mathrm{Zn}^{2+}$.

In Figure $3 \mathrm{D}, \mathrm{E}$, it can be seen that $\mathrm{F}_{\mathrm{V}} / \mathrm{F}_{\mathrm{M}}$ is in the typical range of healthy cells $\left(0 \mathrm{mg} \mathrm{L}{ }^{-1} \mathrm{Zn}^{2+}\right.$ : 0.657; $5 \mathrm{mg} \mathrm{L}{ }^{-1} \mathrm{Zn}^{2+}: 0.663 ; 10 \mathrm{mg} \mathrm{L}^{-1} \mathrm{Zn}^{2+}: 0.642 ; 20 \mathrm{mg} \mathrm{L}^{-1} \mathrm{Zn}^{2+}$ : 0.657). After $72 \mathrm{~h}$ in Figure $3 \mathrm{E}$, it is observed, under different concentrations of $\mathrm{Zn}^{2+}$, in a static system, a decrease in $\mathrm{F}_{\mathrm{V}} / \mathrm{F}_{\mathrm{M}}$ values is shown below 0.4 where the highest value is observed in control $\left(0 \mathrm{mg} \mathrm{L}^{-1} \mathrm{Zn}^{2+}\right)$ with a decrease in $\mathrm{F}_{\mathrm{V}} / \mathrm{F}_{\mathrm{M}}$ from 5, 10, and $20 \mathrm{mg} \mathrm{L}^{-1}$ $\mathrm{Zn}^{2+}$ without significant differences $(p>0.05)$ (Tukey's multiple comparison test).

\section{4. "In Vivo" Fluorescence Analysis for Microalgae Tetraselmis marina AC16-MESO under Different Concentrations of $\mathrm{Zn}^{2+}$}

Histograms of flow cytometry in autofluorescence of Tetraselmis marina AC16-MESO cells are shown in Figure 4. The cell count is along the $Y$-axis and light scattered forward is the $X$-axis (FSC), which is proportional to the size or surface of the cells or particles. The Tetraselmis marina AC16-MESO cells exposed to different concentrations of $\mathrm{Zn}^{2+}$ showed a decrease in fluorescence. This decrease was in the following order: $0 \mathrm{mg} \mathrm{L}{ }^{-1} \mathrm{Zn}^{2+}$ : $83.8 \%<20 \mathrm{mg} \mathrm{L}^{-1} \mathrm{Zn}^{2+}: 77.06 \%<5 \mathrm{mg} \mathrm{L}^{-1} \mathrm{Zn}^{2+}: 69.33 \%<10 \mathrm{mg} \mathrm{L}^{-1} \mathrm{Zn}^{2+}: 64.33 \%$ (Figure 4A-D).

According to Papageorgiou et al. [24] FRAP analysis can be used to assess the mobility of photosynthetic complexes by using the fluorescence recovery time. Microalgae are an excellent model for FRAP because many species have a regular and straightforward thylakoid membrane organization. Therefore, in FRAP analyses at different concentrations of $\mathrm{Zn}^{2+}$, an alteration is seen in the fluorescence recovery time, where the shorter recovery time is observed in control $\left(0 \mathrm{mg} \mathrm{L}^{-1} \mathrm{Zn}^{2+}\right)$. At the same time, the longest recovery time is observed in $20 \mathrm{mg} \mathrm{L}^{-1} \mathrm{Zn}^{2+}$ and the intermediate times in 5 and $10 \mathrm{mg} \mathrm{L}^{-1} \mathrm{Zn}^{2+}$ (Figure 5). 


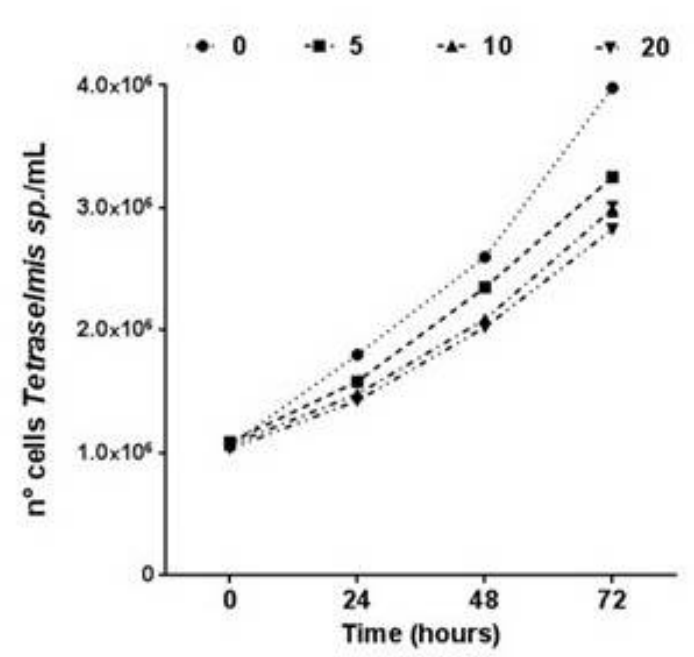

(A)
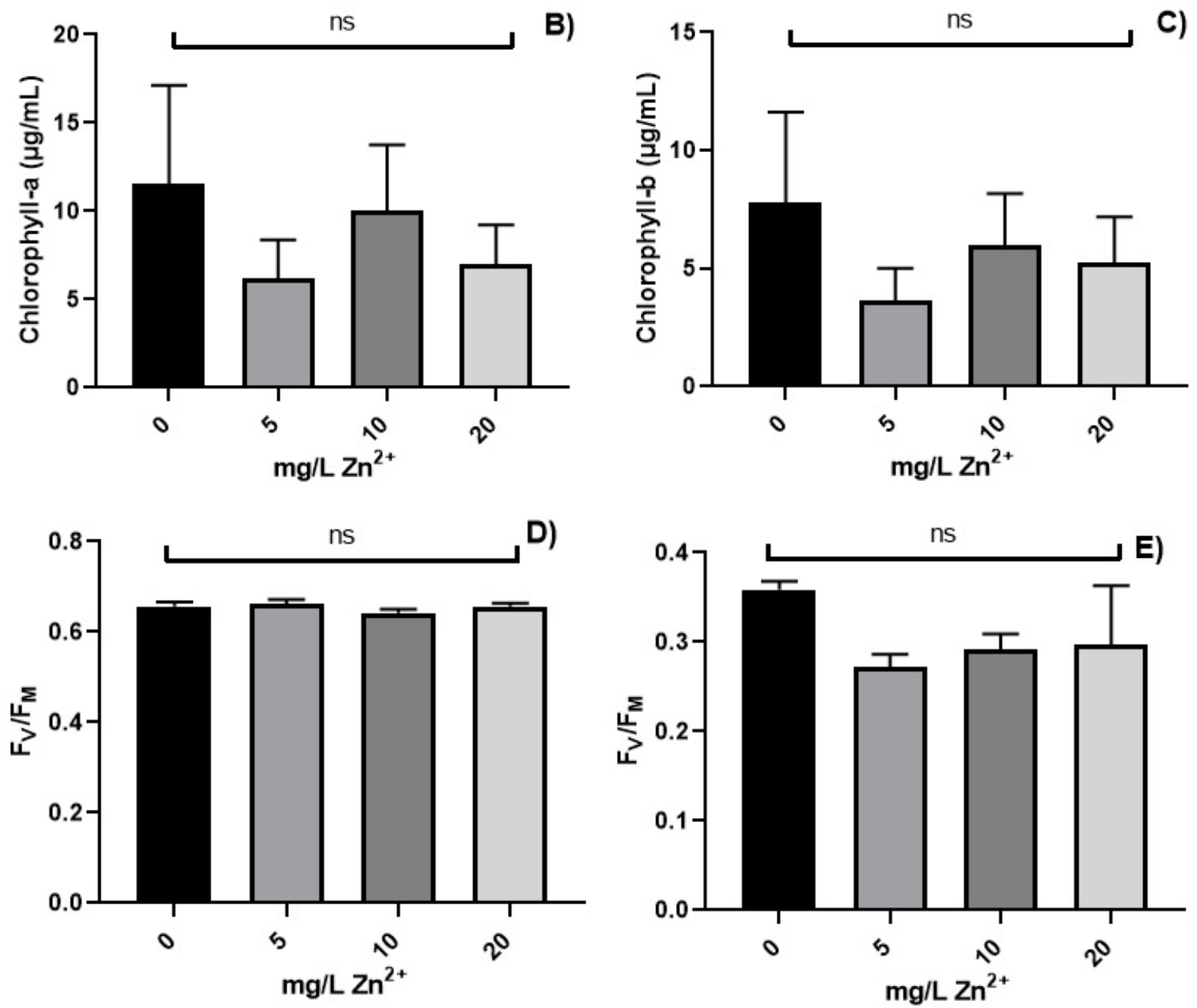

Figure 3. Effect of concentration $\mathrm{Zn}^{2+}(\mathrm{mg} / \mathrm{L})$ : (A) growth microalgal Tetraselmis marina AC16-MESO at 24, 48, and 72 $\mathrm{h}$. Concentrations of the photosynthetic pigment at $72 \mathrm{~h}$ : (B) chlorophyll "a"; (C) chlorophyll "b". Maximum quantum yield $\left(\mathrm{F}_{\mathrm{V}} / \mathrm{F}_{\mathrm{M}}\right)$ in T. marina AC16-MESO at (D) $0 \mathrm{~h}$. (E) $72 \mathrm{~h}$ of exposure. Bars indicate the standard error (SE); ns indicates not significant, $(p>0.05)$. 5 vs $0 ; 10$ vs $0 ; 20$ vs $0\left(\mathrm{mg} / \mathrm{L} \mathrm{Zn}^{2+}\right)$. 

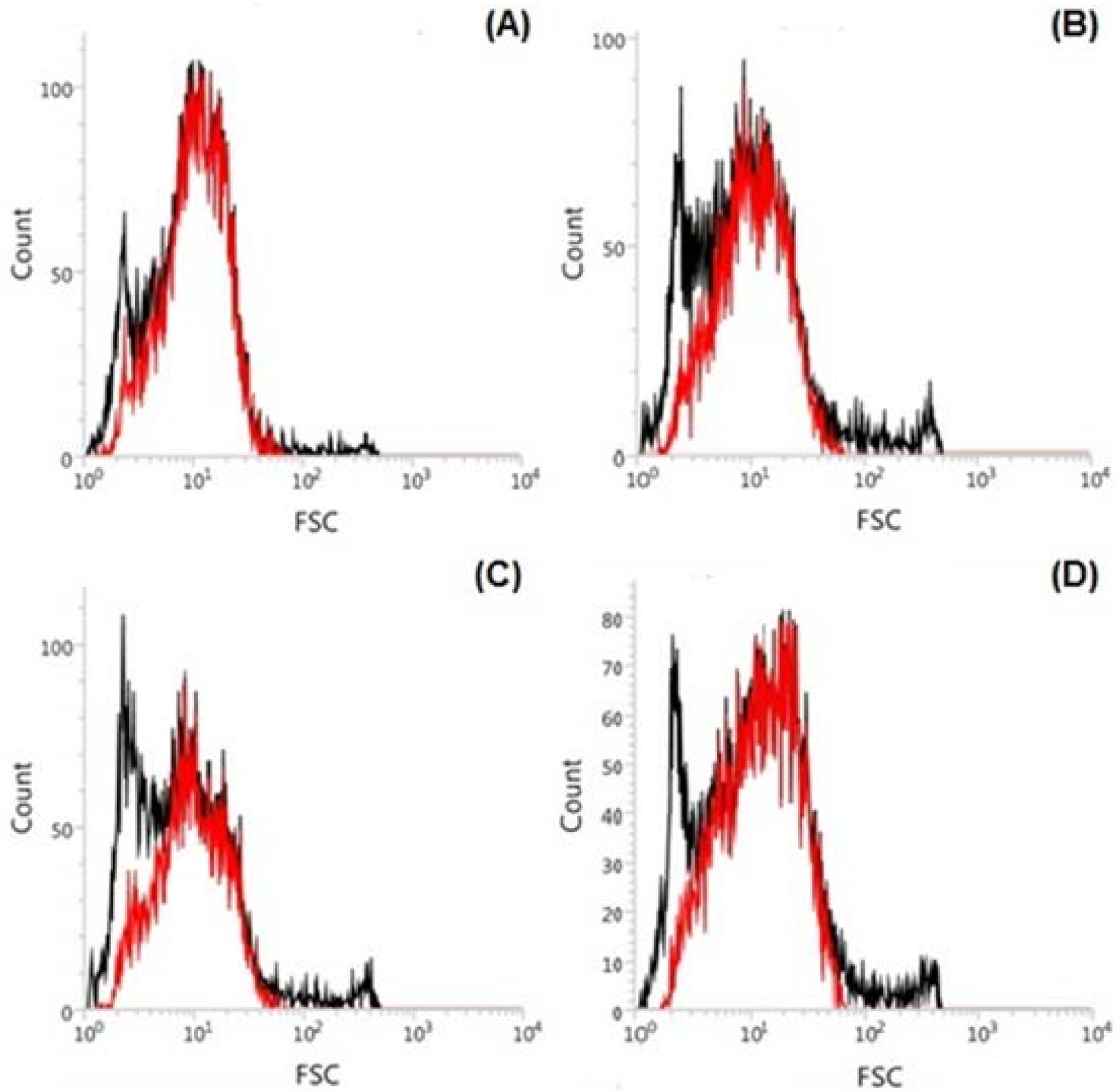

Figure 4. Graphical representation of the autofluorescence signal movement in Tetraselmis marina AC16 MESO (red curves). Flow cytometer histograms representing the excited autofluorescence signal in cells of T. marine AC16 MESO with $488 \mathrm{~nm}$ blue laser, at different concentrations of $\mathrm{Zn}^{2+}$. (A) $0 \mathrm{mg} / \mathrm{L} \mathrm{Zn}^{2+} ;$ (B) $5 \mathrm{mg} / \mathrm{L} \mathrm{Zn}^{2+}$; (C) $10 \mathrm{mg} / \mathrm{L} \mathrm{Zn}^{2+} ;$ (D) $20 \mathrm{mg} / \mathrm{L} \mathrm{Zn}^{2+}$. 

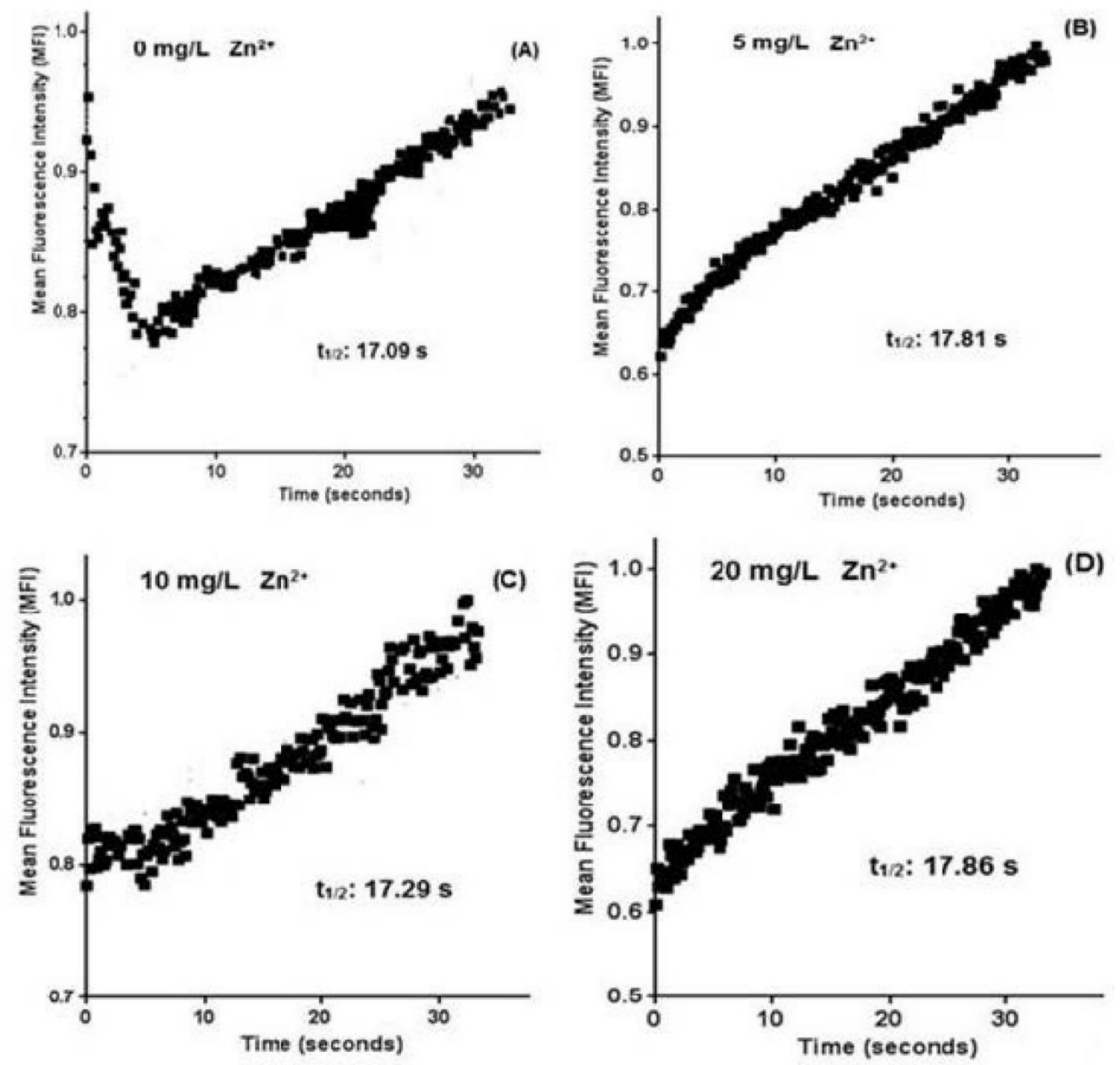

Figure 5. Analysis of fluorescence recovery after photobleaching (FRAP) in autofluorescence of native pigments in microalgae Tetraselmis marina AC16-MESO, at different concentrations of $\mathrm{Zn}^{2+}$ after $72 \mathrm{~h}$ of exposure. (A) $0 \mathrm{mg} \mathrm{L}^{-1}$; (B) $5 \mathrm{mg} \mathrm{L}^{-1}$; (C) $10 \mathrm{mg} \mathrm{L}^{-1}$; (D) $20 \mathrm{mg} \mathrm{L}^{-1}$.

\section{Discussion}

In the optimal quantum yield analysis of photosystem II (PSII, $\left.\mathrm{F}_{\mathrm{V}} / \mathrm{F}_{\mathrm{M}}\right)$ in T. marina AC16 MESO cultures, we saw a decrease in $\mathrm{F}_{\mathrm{V}} / \mathrm{F}_{\mathrm{M}}$ from 0 to $20 \mathrm{mg} \mathrm{L}^{-1} \mathrm{Zn}^{2+}$. This indicates that the chlorophyll fluorescence parameter $\mathrm{F}_{\mathrm{V}} / \mathrm{F}_{\mathrm{M}}$ is dose-dependent and timedependent with $\mathrm{Zn}^{2+}$. Furthermore, the photosynthesis activity of T. marina AC16-MESO was significantly affected by $\mathrm{Zn}^{2+}$. Similar results were found in marine microalgae Nitzschia closterium at different concentrations of $\mathrm{Pb}$ [14].

$\mathrm{Zn}^{2+}$ adsorption capacity was more significant in living biomass than dead biomass of T. marina AC16 MESO microalgae. These findings indicate a higher adsorption capacity of $\mathrm{Zn}^{2+}$ which is in agreement with previous reports conducted on the Qmax values obtained for the adsorption of $\mathrm{Zn}^{2+}\left(1.209 \mathrm{mg} \mathrm{g}^{-1}\right)$ on microalgae Tetraselmis gracilis (Kylin) Butcher and $\mathrm{Zn}^{2+}\left(4.79 \mathrm{mg} \mathrm{g}^{-1}\right)$ in blue green (Cyanophyta) living algae [12]. A strain of Desmodesmus pleiomorphus was isolated from a strongly contaminated industrial site in Portugal. The metal removal by that strain reached a maximum of $360 \mathrm{mg} \mathrm{Zn} \mathrm{g}^{-1}$ biomass after 7 days, at $30 \mathrm{mg} \mathrm{Zn} \mathrm{L}^{-1}$ concentration, in an initial rapid phase of uptake [25]. Suppose the amount of metal added results in solution concentrations exceeding the solubility limit in seawater. In that case, precipitation is predicted to occur, although the kinetics of 
precipitation are often complex, and the degree of precipitation observed will depend on the duration of the toxicity test. Practically, this causes many problems in understanding the concentration and form of metals that organisms are exposed to in seawater. Both dissolved and particulate metal species may be toxic, and the contributions of these forms to toxicity will likely change with time [26]. The biosorption of the heavy metal $\mathrm{Zn}^{2+}$ by dried marine green macroalgae (Chaetomorpha linum) was investigated at different solution $\mathrm{pH}$ values (2-6), different algal particle sizes (100-800 micron), and different initial metal solution concentrations $(0.5-10 \mathrm{mM})$. The dried alga produced maximum zinc uptake values $\left(\mathrm{Q}_{\max }\right)$ of $1.97 \mathrm{mmol} \mathrm{g}^{-1}$ (according to the Langmuir model) [27]. The adsorption for $\mathrm{Zn}\left(0.243 \mathrm{~g} \mathrm{~g}^{-1}\right)$ was obtained on Cyclotella cryptica [28]. The isotherms of Zn sorption by dairy manure at $200{ }^{\circ} \mathrm{C}$ were better fitted to the Langmuir model, where the maximum sorption capacity of $\mathrm{Zn}$ is $31.6 \mathrm{mg} \mathrm{g}^{-1}$ [29]. The accumulation of zinc concentrations was most significant in Dictyota dichotoma with a value of $5.117 \pm 0.017 \mu \mathrm{g} \mathrm{g}^{-1} \mathrm{dry}$ weight. It was relatively uniform in three species of algae, Ulva lactuca, Codium fragile, and Jania rubens at $4.823 \pm 0.010,4.666 \pm 0.006$, and $4.651 \pm 0.017 \mu \mathrm{g} \mathrm{g}^{-1}$ dry weight, respectively [30]. Therefore, live T. marina AC16 MESO biomass exhibited the highest value of maximum adsorption capacity compared to non-living biomass.

A higher concentration of $\mathrm{Zn}^{2+}$ decreases the growth of T. marina AC16-MESO. Similar effects were seen in a study that displayed that nano- $\mathrm{ZnO}$ caused a more potent inhibitory impact on microalgal development than bulk-ZnO. Compared with $\mathrm{Zn}^{2+}$ released by nano$\mathrm{ZnO}$ into medium, lipid peroxidation injury, aggregation of nano- $\mathrm{ZnO}$, and transmembrane process of nano-ZnO also contributed to toxicity [31]. It has been observed that the red microalga was highly resistant to $\mathrm{ZnS}$ nanoparticles, most likely due to the presence of phycoerythrin proteins in the outer membrane-bound $\mathrm{Zn}^{2+}$ cations defending their cells from further toxic influence [32]. However, the dissolved $\mathrm{Zn}^{2+}$ ions can disturb and inhibit photosynthesis and induce oxidative stress in the algal cell. This resulted in the inhibition of the growth of the microalgae [31], where various microalgal species regulate their cellular content of zinc [33]. The cell density from marine microalgae Pleurochrysis roscoffensis after $96 \mathrm{~h}$ exposure to five different $\mathrm{Zn}$ concentrations (50, 100, 500, 1000, and $1500 \mu \mathrm{g} \mathrm{L}^{-1}$ ), and a control (free of added $\mathrm{Zn}$ ), in non-acidified natural seawater revealed significant differences $(p<0.01)$ of microalgae responses between concentrations of 500,1000, and $1500 \mu \mathrm{g} \mathrm{L}^{-1}$ compared with the algae density of the control [34].

In T. marina AC16 MESO, a longer fluorescence recovery time is observed at higher concentrations of $\mathrm{Zn}^{2+}$, possibly due to decoupling in the photosystems located in the chloroplast thylakoidal membrane. In microalgae, large chloroplasts consist of sheets arranged parallel without stacking and occupy most of the intracellular space in vivo. Thus, this organization's regular thylakoid is suitable for FRAP measurements $[19,35]$. As for the thylakoid membrane dynamics, it may be necessary to add fluorescent labels to membrane proteins that are not naturally fluorescent. However, fusions of the green fluorescent protein (GFP) genes do not appear to work in Synechococcus 7942. Yet, GFP can be successfully expressed in other cyanobacteria. Furthermore, many mutant forms are available whose excitation and fluorescence emission do not overlap severely with photosynthetic pigments [36]. In further investigations, direct observations of the fluorescence dynamics of phycoerythrins using FRAP demonstrated energetic decoupling of phycoerythrins in Phycobilisomes (PBsomes) against strong excitation light in vivo, which is projected as a photoprotective mechanism in red algae attributed by the PBsomes in response to excess light energy [37]. The complexity of cellular microenvironments and biological diffusion is often correlated over time and described by a time-dependent diffusion coefficient, $\mathrm{D}(\mathrm{t})$. Many efforts have been made to quantify $\mathrm{D}(\mathrm{t})$ by FRAP. However, straightforward approaches to quantify a general form of $\mathrm{D}(\mathrm{t})$ are still lacking [38].

The living and non-living biomass microalgae Tetraselmis marina AC16-MESO was used as a $\mathrm{Zn}^{2+}$ bioadsorbent. Regarding the experimental equilibrium results, the Langmuir isotherm model defines the results using the $\mathrm{Q}_{\max }$ parameter where the live biomass microalgal $\left(\mathrm{Q}_{\max }=0.03051 \mathrm{mg} \mathrm{g}^{-1}\right)$ value was more significant than the T. marina AC16- 
MESO microalgal dead biomass value $\left(Q_{\max }=0.02297 \mathrm{mg} \mathrm{g}^{-1}\right)$. Therefore, it is concluded that the microalgal T. marina AC16-MESO biomass can be used as a low-cost biosorbent to remove $\mathrm{Zn}^{2+}$ from industrial effluents. Furthermore, in additional investigations conducted on bioadsorption, changes in the fluorescence of microalgae with a decrease in photosystem II activities were observed in the range of $\mathrm{Zn}$ from 0 to $20 \mathrm{mg} \mathrm{L}^{-1}$.

\section{Materials and Methods}

\subsection{Microalgae Culture}

Tetraselmis marina AC16-MESO strain was isolated from the intertidal area of the Bay of San Jorge, Antofagasta, Chile, then identified and preserved in the Marine Mesocosmos Laboratory of the University of Antofagasta, Chile. The strain was cultivated at $20^{\circ} \mathrm{C}$ in Erlenmeyer flasks of $250 \mathrm{~mL}$ using sterilized seawater with the addition of UMA5 medium [39] $\left(\mathrm{NaNO}_{3} 4.55 \times 10^{-5} \mathrm{M} ; \mathrm{NaH}_{2} \mathrm{PO}_{4} \cdot \mathrm{H}_{2} \mathrm{O} 2.41 \times 10^{-4} \mathrm{M} ; \mathrm{NaHCO}_{3} 1.99 \times 10^{-3} \mathrm{M}\right)$ at $20{ }^{\circ} \mathrm{C}$ and with a continuous photosynthetic photon flux of $70 \mu \mathrm{mol} \mathrm{m}{ }^{-2} \mathrm{~s}^{-1}$ ( $24 \mathrm{~h}$ light). The algal cells were counted using a hemocytometer-type chamber in an optic microscope $[40,41]$.

4.2. Evaluation of the PSII of Tetraselmis marina AC16-MESO in a Solid Medium in the Presence of $\mathrm{Zn}^{2+}$

The PSII of Tetraselmis marina AC16-MESO was assessed in $\mathrm{f} / 2$ solid medium $\left(\mathrm{NaNO}_{3}\right.$, $75 \mathrm{~g} \mathrm{~L}^{-1} ; \mathrm{NaH}_{2} \mathrm{PO}_{4} \bullet 2 \mathrm{H}_{2} \mathrm{O} 5.65 \mathrm{~g} \mathrm{~L}^{-1}$ ) [42] containing OXOID marks bacteriological agar at different concentrations of $\mathrm{Zn}^{2+}\left(0,0.5,2,5,10\right.$, and $\left.20 \mathrm{mg} \mathrm{L}^{-1} \mathrm{Zn}^{2+}\right)$. Filtered and autoclaved seawater was used to prepare the medium. The $\mathrm{pH}$ was adjusted to 8 with $1 \mathrm{M}$ $\mathrm{NaOH}$ and $\mathrm{HCl}$, and $15 \mathrm{~g}$ of bacteriological agar per liter was added and autoclaved for 15 min. For the sowing of the microalgae, Tetraselmis marine AC16 MESO was added into the Drigalsky glass handle along with $50 \mu \mathrm{L}$ of liquid culture sample and then emptied into the Petri dishes.

\subsection{Preparation of Living and Non-Living Microalgal Adsorbent Biomass}

The live microalgal biomass of Tetraselmis marine AC16 MESO was used for bioadsorption studies to assess the ability to adsorb at different concentrations $(0,5,10,20 \mathrm{mg}$ $\left.\mathrm{L}^{-1} \mathrm{Zn}^{2+}\right)$. These concentrations are in line with those reported by others in the literature $[43,44]$. The samples were inoculated at $100 \mathrm{~mL}$ of logarithmic phase into $250 \mathrm{~mL}$ Erlenmeyer bottles. Microalgae were added to flasks containing $100 \mathrm{~mL}$ UMA5 medium prepared with sterilized seawater, without trace elements [45]. They were then incubated at $28 \pm 2{ }^{\circ} \mathrm{C}$ and $70 \mathrm{mmol} \mathrm{m}^{-2} \mathrm{~s}^{-1}$, with cold light intensity provided by the white fluorescent lamps for $72 \mathrm{~h}$.

In non-living microalgal biomass assays, the dry biomass used in the adsorption processes was obtained from 2.5 L microalgal culture of non-living Tetraselmis marina AC16 MESO with 2,945,000 cell m L ${ }^{-1}$ equivalent wet weight of $45.6 \mathrm{~g}$. The biomass obtained was washed twice with distilled water. Next, it was frozen and lyophilized [46]. Before using as an adsorbent, the lyophilized biomass was ground and homogenized to obtain a "non-living" microalgal biomass wherein each experimental unit contains $0.5 \mathrm{~g}$ of dry biomass in a volume of $40 \mathrm{~mL}$ of sterile seawater at $0.5,10$, and $20 \mathrm{mg} \mathrm{L}^{-1}$ of $\mathrm{Zn}^{2+}$ with a test time of $72 \mathrm{~h}$.

\subsection{Adsorbent Biomass and Adsorption Experiments}

To measure $\mathrm{Zn}^{2+}$ in living and non-living biomass of the Tetraselmis marina AC16MESO microalgae, 0.5 and $1 \mathrm{~g}$ of microalgal biomass sample (in triplicate) was homogenized using an agate mortar in a reflux system with a glass funnel covered with a watch glass. The pieces were placed in a $125 \mathrm{~mL}$ beaker for disintegration with $10 \mathrm{~mL}$ of $\mathrm{HNO}_{3}$ Suprapur and heated on a heating plate at $150{ }^{\circ} \mathrm{C}$ for $2 \mathrm{~h}$. Subsequently, the resulting solution was filtered $(0.45 \mu \mathrm{m})$ and packed into a $25 \mathrm{~mL}$ volumetric flask with deionized water. The quantification of metals was performed by atomic absorption spectrophotome- 
try (Shimadzu, AA 6300) by using the flame technique at a wavelength of $213.9 \mathrm{~nm}$ with a mixture of $\mathrm{C}_{2} \mathrm{H}_{2}$ gas. The concentrations were expressed as $\mathrm{mg} \mathrm{g}^{-1}$ wet weight [47].

\subsection{Langmuir Equation}

The balance of the adsorption isotherm of $\mathrm{Zn}^{2+}$ was calculated using the Langmuir sorption model [48] with the Origin6 program to determine the maximum adsorption of $\mathrm{Zn}^{2+}$ in "living" and "non-living" cells of Tetraselmis marina AC16-MESO. The adsorption of $\mathrm{Zn}^{2+}(\mathrm{q})$ for the construction of adsorption isotherms was determined using the following equation:

$$
\mathrm{q}=\mathrm{q}_{\max } \mathrm{bC}_{\mathrm{f}} /\left(1+\mathrm{bC}_{\mathrm{f}}\right)
$$

where $\mathrm{q}$ is the adsorption of $\mathrm{Zn}^{2+}$ (mg $\mathrm{Zn}^{2+} \mathrm{g}^{-1}$ dry biomass), $\mathrm{q}_{\max }$ is the maximum

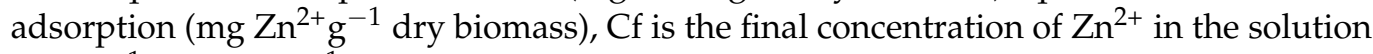
$\left(\mathrm{mg} \mathrm{L}^{-1}\right), \mathrm{b}\left(\mathrm{L} \mathrm{mg}^{-1}\right)$ is the Langmuir constant. Here, adsorption rate is equal to the desorption ratio. For the preparation of experimental data, the Langmuir model was linearized using the following equation:

$$
\mathrm{C}_{\mathrm{f}} / \mathrm{q}=\left(1 / \mathrm{q}_{\max } \mathrm{b}\right)+\left(\mathrm{C}_{\mathrm{f}} / \mathrm{q}_{\max }\right)
$$

\subsection{Determination of Chlorophylls " $a$ " and " $b$ "}

For the quantification of chlorophyll, $2 \mathrm{~mL}$ of Tetraselmis marina AC16-MESO cell culture were taken for centrifugation and alteration in a sonicator (ultrasonic bath) for $7 \mathrm{~min}(20 \mathrm{kHz})$ by extracting with $2 \mathrm{~mL}$ of acetone. The extract was centrifuged at $3000 \times g$ for $5 \mathrm{~min}$, and the optical density was measured at 647 and $664 \mathrm{~nm}$ [49]. The concentrations of chlorophyll a and chlorophyll $\mathrm{b}\left(\mu \mathrm{g} \mathrm{mL} \mathrm{m}^{-1}\right)$ can be calculated based on optical density values as follows:

$$
\begin{gathered}
\mathrm{Chl} \mathrm{a}=-1.93 \times \mathrm{OD}_{647}+11.93 \times \mathrm{OD}_{664} \\
\mathrm{Chl} \mathrm{b}=20.63 \times \mathrm{OD}_{647}-5.5 \times \mathrm{OD}_{664}
\end{gathered}
$$

4.7. Measurement of the Fluorescence of Chlorophyll a (Chl-a) in the Living Culture of Tetraselmis marina AC16-MESO

The maximum quantum yield of PSII $\left(\mathrm{F}_{\mathrm{V}} / \mathrm{F}_{\mathrm{M}}\right)$ of Tetraselmis marina AC16-MESO exposed to $0,5,10$, and $20 \mathrm{mg} \mathrm{L}^{-1} \mathrm{Zn}^{2+}$ was measured in triplicate after 10 min of adapting to darkness by using pulse amplitude modulated chlorophyll fluorometer (JUNIOR-PAM WALZ, Germany). The maximum quantum yield of photosystem II, $\mathrm{F}_{\mathrm{V}} / \mathrm{F}_{\mathrm{M}}$, was calculated according to Schreiber [50]:

$$
\mathrm{F}_{\mathrm{V}} / \mathrm{F}_{\mathrm{M}}=\left(\mathrm{F}_{\mathrm{M}}-\mathrm{F}_{0}\right) / \mathrm{F}_{\mathrm{M}}
$$

\subsection{Flow Cytometric Analysis}

The microalgal cells from Tetraselmis marina AC16-MESO at different concentrations of $\mathrm{Zn}^{2+}$ were suspended in $500 \mu \mathrm{L}$ of the same medium with $3 \%$ formalin, and the autofluorescence emitted due to chlorophyll was observed. The size and complexity of the cells were determined using a BD FACSVerse ${ }^{\mathrm{TM}}$ flow cytometer equipped with an air-cooled $488 \mathrm{~nm}$ argon-ion laser exciting the cells at that wavelength.

\subsection{Fluorescence Recovery after Photobleaching (FRAP) Analysis in Microalgal Autofluorescence} from Tetraselmis marina AC16-MESO

In the FRAP analysis, live Tetraselmis marina AC16-MESO cells immobilized on a slide covered with a glass slip were observed under the objective lens of confocal spectral microscopy at different concentrations of $\mathrm{Zn}^{2+}\left(0,5,10\right.$, and $\left.20 \mathrm{mg} \mathrm{L}^{-1}\right)$. Due to the autofluorescence of the microalgae, images were obtained using a TCS SP8 Confocal Spectral microscopy system, mARK Leica, with a 40X objective. Photobleaching was performed in an area marked ROI in the microalgal cell. ROI areas were bleached with $100 \%$ Argon- 405 power laser, and the images were grouped $2 \times 2$ to increase signal noise per camera. 
After opening the laser shutter for 448 milliseconds (ms), images of the cells were taken by microscopy every $0.148 \mathrm{~s}$ for pre-whitening, bleaching, and post-whitening with a total duration of $448 \mathrm{~ms}$ and a total exposure time of $32.55 \mathrm{~s}$. Then, the results were exported to Excel. The fluorescence intensity was calculated as MFI. The final data were analyzed using Graph Pad Prism 6.0.

\subsection{Data Analysis and Statistics}

For the study, the alteration of FRAP in Tetraselmis marina AC16-MESO at different concentrations $\left(0,5,10\right.$, and $\left.20 \mathrm{mg} \mathrm{L}^{-1}\right)$ of $\mathrm{Zn}^{2+}$ were evaluated using the cell growth, maximum photochemical efficiency, fluorescence, and fluorescence recovery after photobleaching (FRAP) analysis. The mean and standard error were calculated to obtain a representative "average" at the end of $72 \mathrm{~h}$. The ANOVA was performed with three repetitions in each treatment. The results were considered significant at $p<0.05$.

Author Contributions: Conceptualization, R.H.-O.; M.T.M. and C.R.; methodology, R.H.-O.; writing - original draft preparation, R.H.-O.; analyzed the data, contributed reagents/materials/analysis tools, authored or reviewed drafts of the paper, approved the final draft. M.T.M. and C.R.; methodology adsorption, J.V. All authors have read and agreed to the published version of the manuscript.

Funding: This research was funded by CONICYT, Chile through grant PAI/Concurso Nacional Inserción de Capital Humano avanzado en la Academia, convocatoria año 2017, Folio n ${ }^{\circ}$ PAI79170067.

Institutional Review Board Statement: Not applicable.

Informed Consent Statement: Not applicable.

Data Availability Statement: Data available upon request.

Conflicts of Interest: The authors declare no conflict of interest.

\section{References}

1. Kumar, K.S.; Dahms, H.U.; Won, E.J.; Lee, J.S.; Shin, K.H. Microalgae-A promising tool for heavy metal remediation. Ecotoxicol. Environ. Saf. 2015, 113, 329-352. [CrossRef] [PubMed]

2. Leong, Y.K.; Chang, J.S. Bioremediation of heavy metals using microalgae: Recent advances and mechanisms. Bioresour. Technol. 2020, 303, 122886. [CrossRef]

3. Duruibe, J.O.; Ogwuegbu, M.O.C.; Egwurugwu, J.N. Heavy metal pollution and human biotoxic effects. Int. J. Phys. Sci. 2007, 2, 112-118.

4. Sun, J.; Cheng, J.; Yang, Z.; Li, K.; Zhou, J.; Cen, K. Microstructures and functional groups of Nannochloropsis sp. cells with arsenic adsorption and lipid accumulation. Bioresour. Technol. 2015, 194, 305-311. [CrossRef] [PubMed]

5. Nolan, K. Copper Toxicity Syndrome. J. Orthomol. Psychiatry 2003, 12, 270-282.

6. Moon, W.J.; Yang, Y.; Liu, J. $\mathrm{Zn}^{2+}$-Dependent DNAzymes: From Solution Chemistry to Analytical, Materials and Therapeutic Applications. ChemBioChem. 2020. [CrossRef]

7. Salamanca, M.A.; Camaño, A.; Jara, B.; Rodriguez, T. Cu, Pb and Zn Distribution in nearshore waters in San Jorge bay, northern Chile. Gayana (Concepc.) 2000, 64. [CrossRef]

8. Fukai, R.; Huynh-Ngoc, L. Chemical forms of zinc in sea water. J. Oceanogr. 1975, 31, 179-191. [CrossRef]

9. Ibuot, A.; Dean, A.P.; McIntosh, O.A.; Pittman, J.K. Metal bioremediation by CrMTP4 over-expressing Chlamydomonas reinhardtii in comparison to natural wastewater-tolerant microalgae strains. Algal Res. 2017, 24, 89-96. [CrossRef]

10. Pradhan, D.; Sukla, L.B.; Mishra, B.B.; Devi, N. Biosorption for removal of hexavalent chromium using microalgae Scenedesmus sp. J. Clean. Prod. 2019, 209, 617-629. [CrossRef]

11. Nazal, M.K. Marine Algae Bioadsorbents for Adsorptive Removal of Heavy Metals. In Advanced Sorption Process Applications; IntechOpen: London, UK, 2019. [CrossRef]

12. Abbas, S.H.; Ali, W.H. Evaluation of biomass type blue Cyanophyta algae for the sorption of $\mathrm{Cr}$ (III), Zn (II) and Ni (II) from aqueous solution using batch operation system: Equilibrium, kinetic and thermodynamic studies. Glob. Nest J. 2018, $20,69-82$. [CrossRef]

13. Banks, J.M. Chlorophyll fluorescence as a tool to identify drought stress in Acer genotypes. Environ. Exp. Bot. 2018, 155, 118-127. [CrossRef]

14. Gan, T.; Zhao, N.; Yin, G.; Chen, M.; Wang, X.; Liu, J.; Liu, W. Optimal chlorophyll fluorescence parameter selection for rapid and sensitive detection of lead toxicity to marine microalgae Nitzschia closterium based on chlorophyll fluorescence technology. J. Photochem. Photobiol. B, Biol. 2019, 197, 111551. [CrossRef] 
15. Kumar, K.S.; Dahms, H.U.; Lee, J.S.; Kim, H.C.; Lee, W.C.; Shin, K.H. Algal photosynthetic responses to toxic metals and herbicides assessed by chlorophyll a fluorescence. Ecotoxicol. Environ. Saf. 2014, 104, 51-71. [CrossRef]

16. Huang, H.; Xiao, X.M.; Ghadouani, A.; Wu, J.; Nie, Z.; Peng, C.; Xu, X.; Shi, J. Effects of natural flavonoids on photosynthetic activity and cell integrity in Microcystis aeruginosa. Toxins 2015, 7, 66-80. [CrossRef]

17. Axelrod, D.; Koppel, D.E.; Schlessinger, J.; Elson, E.; Webb, W.W. Mobility measurement by analysis of fluorescence photobleaching recovery kinetics. Biophys. J. 1976, 16, 1055-1069. [CrossRef]

18. Lippincott-Schwartz, J.; Altan-Bonnet, N.; Patterson, G.H. Photobleaching and photoactivation: Following protein dynamics in living cells. Nat. Cell Biol. 2003, Suppl, S7-S14. [PubMed]

19. Mullineaux, C.W. FRAP analysis of photosynthetic membranes. J. Exp. Bot. 2004, 55, 1207-1211. [CrossRef] [PubMed]

20. Mullineaux, C.W.; Tobin, M.J.; Jones, G.R. Mobility of photosynthetic complexes in thylakoid membranes. Nature 1997, 390, 421-424. [CrossRef]

21. Mullineaux, C.W.; Kirchhoff, H. Role of lipids in the dynamics of thylakoid membranes. In Lipids in Photosynthesis. Advances in Photosynthesis and Respiration; Springer: Dordrecht, The Netherlands, 2009; pp. 283-294.

22. Cameron, H.; Mata, M.T.; Riquelme, C. The effect of heavy metals on the viability of Tetraselmis marina AC16-MESO and an evaluation of the potential use of this microalga in bioremediation. PeerJ 2018, 6, e5295. [CrossRef] [PubMed]

23. Otero, M.; Zabkova, M.; Grande, C.A.; Rodrigues, A.E. Fixed-bed adsorption of salicylic acid onto polymeric adsorbents and activated charcoal. Ind. Eng. Chem. Res. 2005, 44, 927-936. [CrossRef]

24. Chlorophyll a Fluorescence: A Signature of Photosynthesis; Papageorgiou, G.C. (Ed.) Springer Science \& Business Media: Dordrecht, The Netherlands, 2007; pp. 1-793.

25. Monteiro, C.M.; Marques, A.P.; Castro, P.M.; Malcata, F.X. Characterization of Desmodesmus pleiomorphus isolated from a heavy metal-contaminated site: Biosorption of zinc. Biodegradation 2009, 20, 629-641. [PubMed]

26. Angel, B.M.; Apte, S.C.; Batley, G.E.; Raven, M.D. Lead solubility in seawater: An experimental study. Environ. Chem. 2016, 13, 489-495. [CrossRef]

27. Ajjabi, L.C.; Chouba, L. Biosorption of $\mathrm{Cu}^{2+}$ and $\mathrm{Zn}^{2+}$ from aqueous solutions by dried marine green macroalga Chaetomorpha linum. J. Environ. Manag. 2009, 90, 3485-3489. [CrossRef] [PubMed]

28. Schmitt, D.; Müller, A.; Csögör, Z.; Frimmel, F.H.; Posten, C. The adsorption kinetics of metal ions onto different microalgae and siliceous earth. Water Res. 2001, 35, 779-785. [CrossRef]

29. Xu, X.; Cao, X.; Zhao, L.; Wang, H.; Yu, H.; Gao, B. Removal of $\mathrm{Cu}, \mathrm{Zn}$, and $\mathrm{Cd}$ from aqueous solutions by the dairy manure-derived biochar. Environ. Sci. Pollut. Res. 2013, 20,358-368. [CrossRef]

30. Laib, E.; Leghouchi, E. Cd, Cr, Cu, Pb, and $\mathrm{Zn}$ concentrations in Ulva lactuca, Codium fragile, Jania rubens, and Dictyota dichotoma from Rabta Bay, Jijel (Algeria). Environ. Monit. Assess. 2012, 184, 1711-1718. [CrossRef]

31. Zhang, C.; Wang, J.; Tan, L.; Chen, X. Toxic effects of nano-ZnO on marine microalgae Skeletonema costatum: Attention to the accumulation of intracellular Zn. Aquat. oxicol. 2016, 178, 158-164. [CrossRef]

32. Pikula, K.; Mintcheva, N.; Kulinich, S.A.; Zakharenko, A.; Markina, Z.; Chaika, V.; Orlova, T.; Mezhuev, Y.; Kokkinakis, E.; Tsatsakis, A.; et al. Aquatic toxicity and mode of action of CdS and ZnS nanoparticles in four microalgae species. Environ. Res. 2020, 186, 109513. [CrossRef]

33. Knauer, K.; Behra, R.; Sigg, L. Effects of free $\mathrm{Cu}^{2+}$ and $\mathrm{Zn}^{2+}$ ions on growth and metal accumulation in freshwater algae. Environ. Toxicol. Chem. 1997, 16, 220-229. [CrossRef]

34. Bautista-Chamizo, E.; De Orte, M.R.; DelValls, T.Á.; Riba, I. Simulating $\mathrm{CO}_{2}$ leakages from CCS to determine $\mathrm{Zn}$ toxicity using the marine microalgae Pleurochrysis roscoffensis. Chemosphere 2016, 144, 955-965. [CrossRef] [PubMed]

35. Mullineaux, C.W.; Sarcina, M. Probing the dynamics of photosynthetic membranes with fluorescence recovery after photobleaching. Trends Plant Sci. 2002, 7, 237-240. [CrossRef]

36. Spence, E.; Sarcina, M.; Ray, N.; Møller, S.G.; Mullineaux, C.W.; Robinson, C. Membrane-specific targeting of green fluorescent protein by the Tat pathway in the cyanobacterium Synechocystis PCC6803. Mol. Microbiol. 2003, 48, 1481-1489. [CrossRef] [PubMed]

37. Liu, L.N.; Aartsma, T.J.; Thomas, J.C.; Zhou, B.C.; Zhang, Y.Z. FRAP analysis on red alga reveals the fluorescence recovery is ascribed to intrinsic photoprocesses of phycobilisomes than large-scale diffusion. PLoS ONE 2009, 4, e5295. [CrossRef]

38. Kang, M.; Day, C.A.; Kenworthy, A.K. A novel computational framework for D(t) from Fluorescence Recovery after Photobleaching data reveals various anomalous diffusion types in live cell membranes. Traffic 2019, 20, 867-880. [CrossRef]

39. Riveros, K.; Sepulveda, C.; Bazaes, J.; Marticorena, P.; Riquelme, C.; Acién, G. Overall development of a bioprocess for the outdoor production of Nannochloropsis gaditana for aquaculture. Aquac. Res. 2018, 49, 165-176. [CrossRef]

40. Rigobello-Masini, M.; Aidar, E.; Masini, J.C. Extra and intracelular activities of carbonic anhydrase of the marine microalga Tetraselmis gracilis (Chlorophyta). Braz. J. Microbiol. 2003, 34, 267-272. [CrossRef]

41. Rigobello-Masini, M.; Masini, J.C.; Aidar, E. The profiles of nitrate reductase and carbonic anhydrase activity in batch cultivation of the marine microalgae Tetraselmis gracilis growing under different aeration conditions. FEMS Microbiol. Ecol. 2006, 57, 18-25. [CrossRef] [PubMed]

42. Guillard, R.R. Culture of phytoplankton for feeding marine invertebrates. In Culture of Marine Invertebrate Animals; Springer: Boston, MA, USA, 1975; pp. 29-60. 
43. Zhou, G.J.; Peng, F.Q.; Zhang, L.J.; Ying, G.G. Biosorption of zinc and copper from aqueous solutions by two freshwater green microalgae Chlorella pyrenoidosa and Scenedesmus obliquus. Environ. Sci. Pollut. Res. 2012, 19, 2918-2929. [CrossRef]

44. Alam, M.A.; Wan, C.; Zhao, X.Q.; Chen, L.J.; Chang, J.S.; Bai, F.W. Enhanced removal of $\mathrm{Zn}^{2+}$ or $\mathrm{Cd}^{2+}$ by the flocculating Chlorella vulgaris JSC-7. J. Hazard. Mater. 2015, 289, 38-45. [CrossRef]

45. Goldman, J.C.; McCarthy, J.J. Steady state growth and ammonium uptake of a fast-growing marine diatom. Limnol. Oceanogr. 1978, 23, 695-703. [CrossRef]

46. Coimbra, R.N.; Escapa, C.; Vázquez, N.C.; Noriega-Hevia, G.; Otero, M. Utilization of non-living microalgae biomass from two different strains for the adsorptive removal of diclofenac from water. Water 2018, 10, 1401. [CrossRef]

47. Castillo, A.; Valdés, J. Contenido de metales en Cancer polyodon (Crustacea: Decapoda) en un sistema de bahías del norte de Chile (27S). Lat. Am. J. Aquat. Res. 2011, 39, 461-470. [CrossRef]

48. Langmuir, I. The adsorption of gases on plane surfaces of glass, mica and platinum. J. Am. Chem. Soc. 1918, 40, 1361-1403. [CrossRef]

49. Jeffrey, S.W.; Humphrey, G.F. New spectrophotometric equations for determining chlorophylls a, b, c1 and c2 in higher plants, algae and natural phytoplankton. Biochem Physiol Pflanz J. 1975, 165, 191-194. [CrossRef]

50. Schreiber, U. Pulse-amplitude-modulation (PAM) fluorometry and saturation pulse method: An overview. Chlorophyll Fluoresc. 2004, 279-319. [CrossRef] 